\title{
Design and study of telomerase inhibitors based on G-quadruplex ligands
}

\author{
V. V. Negrutska, L. V. Dubey, M. M. Ilchenko, I. Ya. Dubey \\ Institute of Molecular Biology and Genetics, NAS of Ukraine \\ 150, Akademika Zabolotnogo Str., Kyiv, Ukraine, 03680 \\ dubey@imbg.org.ua
}

\begin{abstract}
In this review we have summarized the results of our recent research on telomerase inhibitors and G-quadruplex DNA ligands. A series of potential enzyme inhibitors were synthesized and studied. These compounds were based on tricyclic heteroaromatic systems (thiazolobenzimidazoles phenazines, acridones), amino-substituted cyanines and natural and synthetic porphyrins and their metalocomplexes. A number of compounds, including cyanines and especially porphyrin derivatives and conjugates, were found to efficiently inhibit telomerase at low micromolar concentrations in the in vitro TRAP assay. Porphyrins demonstrated antiproliferative activity in tumor cell cultures at micro- and nanomolar concentrations. Spectral-fluorescent and electrophoretic experiments were performed to investigate the interaction of ligands with duplex and quadruplex DNA, and in many cases binding mode was established. Convenient G-octet model of G-quadruplex was developed to study the ligand-target binding using quantum-chemical methods. QM/MM hybrid approach ONIUM2 was employed to model the interaction of small molecules with Tel22 quadruplex DNA.
\end{abstract}

Keywords: telomerase, G-quadruplex, TRAP, antitumor agents, porphyrins, molecular modeling.

Inhibition of telomerase and quadruplex DNA. Quite recently emerged antitumor strategy is based on the use of small molecules that specifically target telomeres and telomerase [1-4]. Telomeres are guanine-rich DNA sequences localized at the ends of the chromosomes. They protect chromosomal DNA from degradation, prevent end-to-end fusion and other forms of aberrant recombination, and allow it to be completely replicated without loss of genetic material. The length of the telomeres correlates with the ability of a cell to undergo a large number of cell divisions. Normally telomeric DNA is shortened by 50-200 nucleotides upon each cellular division that may control the proliferative capacity of normal somatic cells. However, this does not occur in tumor cells due to high activity of telomerase, an enzyme which is responsible for maintaining the telomere length and synthesizes the lost telomeric sequences by adding telomeric repeats (5'-TTAGGG-3' sequence in humans), that leads to uncontrolled proliferation. Inhi-

(C) Institute of Molecular Biology and Genetics, NAS of Ukraine, 2013 bition of telomerase activity induces senescence in cancer cells followed by their death.

In contrast, normal somatic cells are devoid of telomerase activity, so high level of enzyme expression is directly associated with tumor cells. Indeed, increased telomerase activity was de tected in $85-90 \%$ of human tumors $[1,3]$. That's why telomerase system is now considered a promising molecular target for anticancer drugs.

Telomerase is a complex highly specialized reverse transcriptase (RT) utilizing its own RNA component (hTR) as a template to synthesize telomeric repeats. Current approaches to inhibit telomerase by small molecules include the application of nucleoside and non-nucleoside RT inhibitors, antisense oligonucleotide analogues against hTR, ribozymes and siRNA [5-9]. These approaches are rather traditional for the control of gene expression and the inhibition of enzymes of nucleic acids biosynthesis.

However, we have concentrated on the other possibility that is based on the presence of specific structural motifs in telomeric DNA. 


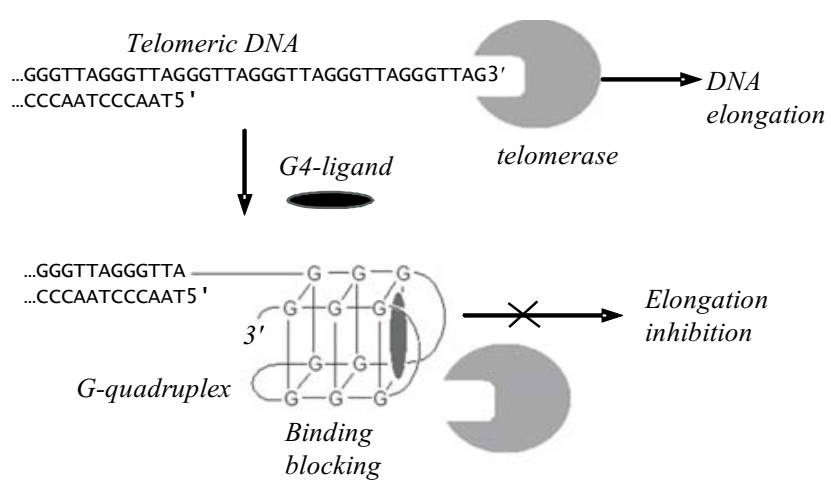

Fig. 1. Mechanism of telomerase inhibition by G-quadruplex ligands

Guanine-rich DNA sequences can adopt unique high-order structures called G-quadruplexes (G4) formed by stacked arrays of guanine quartets connected by non-canonical Hoogsteen-type hydrogen bonds. These DNA arrangements were shown to play a crucial biological role. DNA sequences able to fold into G4 structures are prevalent in telomeres, but they have been also found in a number of gene promoter regions, first of all in proto-oncogenes like $c$-myc or k-ras [10-13].

G-quadruplexes are specific DNA structures that include planar G-quartet stacks and four grooves providing different geometries and spatial distribution of functional groups relative to duplex DNA, so they allow selective recognition by small molecules. The strong binding of a drug onto the telomeres inhibits telomerase, and subsequent decrease of the telomeres length in cancer cells stops their proliferation. Selective quadruplex ligands stabilizing G4 structures may disturb the binding of enzyme to telomeric DNA and block its elongation that results in anticancer activity $[4,5,7,10]$. By this elegant approach the enzyme inhibition is achieved via the interaction of drugs with its substrate, telomeric DNA, rather than telomerase itself, so they can be considered indirect enzyme inhibitors (Fig. 1).

A number of efficient quadruplex binding/stabilizing ligands with anticancer properties were reported (e. g. BRACO-19, telomestatin, BMVC, Quarfloxin). They are usually based on heteroaromatic structures like acridines, anthraquinones, carbazoles, macrocyclic polyoxazoles, etc. [5, 7, 14-16]. Generally, stabilization of quadruplex conformations by small molecules can occur via the $\pi-\pi$ interaction of cationic or neutral aromatic fragments with G-quartets (usually external stacking at the terminal G-quartet) and by the electrostatic interaction of positively charged ligands, either aromatic cores or cationic or easily protonated basic substituents, with G4 DNA polyphosphate backbone [14-16]. The design of G4 ligands is mainly based on planar polycyclic aromatic scaffolds able to interact with G-quartets via the stacking mechanism.

Study on tricyclic heterocycles and cyanines as telomerase inhibitors. Research on G4 binders and telomerase inhibitors started at the Department of Synthetic Bioregulators in 2008. Since then, we have synthesized and studied dozens of heterocyclic compounds of many classes, including the derivatives of tricyclic systems (thiazolobenzimidazoles, phenazines, acridones), cyanines and porphyrins (Fig. 2, 3).

The inhibition of telomerase was investigated in vitro using the TRAP assay (Telomeric Repeat Amplification Protocol) that allows direct analysis of enzymatic activity $[17,18]$. It should be noted that the separation of inhibitor from the reaction mixture after the first step of TRAP (telomerase reaction) before PCR amplification is crucial for obtaining correct activity data. This is because many compounds (e. $g$. some acridones and cyanines) inhibit Taq-DNA-polymerase while not affecting telomerase. This may result in false-positive results in two-step TRAP assay.

2-Aryl(hetaryl)idene-substituted benzimidazothiazolone (1) known as potent transcription inhibitors [19] were found to be inactive in TRAP assay.

An extensive series of phenazine, acridone and thioxanthone derivatives (2-3), including those with a neutral benzazole fragment or basic or cationic substituent (dimethylamino, trimethylammonium or N-methylpyridinium group) at $\mathrm{C}-1$ or $\mathrm{C}-4$ position of heterocycles, were prepared (Dr. V. Kostina, N. Lysenko). Tested compounds were not efficient inhibitors, with rather low level of activity of some derivatives at $50-100 \mu \mathrm{M}$ concentration. Perhaps this is due to both the relatively small size of the core molecules and the presence of a single substituent interacting with a phosphate. Now we are working on the modification of these structures with the second basic/cationic group. Indeed, efficient tricyclic G4 ligands usually contain at least two substituents of this type $[5,7,14-16]$.

A number of 2-amino-substituted cyanines (4), structural analogs of Thiazole Orange dye, were then obtained (Dr. D. Kryvorotenko). These compounds contain 
<smiles>[R]C=c1sc2nc3ccccc3n2c1=O</smiles>

1

$R=A r$, Het<smiles>[X]C1=CC=CC=c2[Y]c3cccc(C(=O)NP)c3cc21</smiles>

2

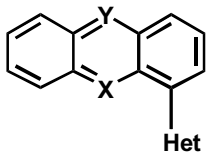

3

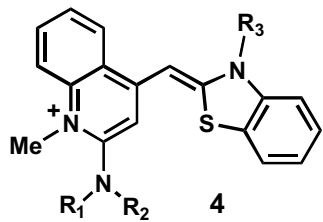

$\mathbf{R}_{\mathbf{1}}, \mathbf{R}_{\mathbf{3}}=$ Alk; $\mathbf{R}_{\mathbf{2}}=$ Alk, Ar

, 3: $\mathrm{X}=\mathrm{N}, \mathrm{S}$; $\mathrm{Y}=\mathrm{N}, \mathrm{C}-\mathrm{OH}$<smiles>C[n+]1ccccc1Cc1ccccc1</smiles>

6a: $R=O M e$

6b: $\mathrm{R}=\mathrm{NHCH}_{2} \mathrm{CH}_{2} \mathrm{CH}_{2} \mathrm{NMe}_{3}{ }^{+}$

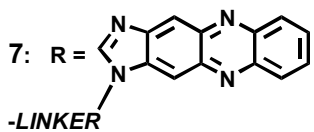

LINKER $=-\mathrm{NHCH}_{2} \mathrm{CH}_{2} \mathrm{CH}_{2}(7 \mathrm{a})$; $-\mathrm{NHCH}_{2} \mathrm{CH}_{2} \mathrm{CONHCH}_{2} \mathrm{CH}_{2}$ (7b)
Fig. 2. Structures of tricyclic compounds $(1-3)$ and cyanines $(4)$
Fig. 3. Derivatives of Pheophorbide- $a(5)$ and TMP3 $(6,7)$ rather large aromatic fragment, along with a basic substituent. The size and structure of aromatic core with a delocalized positive charge allows its efficient $\pi-\pi$ interaction with two guanine residues of G-quartet. These derivatives demonstrated quite high inhibitory activity in the TRAP assay. Five compounds were found to inhibit telomerase at $40 \mu \mathrm{M}$ concentration. At lower concentrations the effect decreased, however, two compounds were still able to completely inhibit enzyme at $20 \mu \mathrm{M}$. Cyanine with 2-methylbenzylamino substituent demonstrated significant activity at $10 \mu \mathrm{M}$. So, cyanines appeared to be active telomerase inhibitors at micromolar concentrations.

On the other hand, some cyanines were found to inhibit also Taq-DNA-polymerase at $10 \mu \mathrm{M}$ concentration. Spectral-fluorescent studies and electrophoretic experiments revealed the strong binding of cyanines to duplex DNA to form highly fluorescent complexes. Thus, cyanines have a good potential as telomerase inhibitors, however, their structures require further optimization to increase inhibitory activity and selectivity to telomerase and quadruplex over duplex DNA.

Porphyrin derivatives and their interaction with DNA. G-quartet consists of four guanine bases, so its square is twice as large as the square of the base pair. Due to this large area of G-quartet, a specific quadruplex binder should have a large aromatic/heteroaromatic surface, larger than that required for duplex ligands. Only in this case G4 ligand would provide an efficient overlap with its target and good quadruplex selectivity over the duplex DNA $[7,14,15]$. Although molecular modeling demonstrated the ability of our tricyclic compounds to bind to quadruplex DNA, these molecules seem to be too small for the efficient $\pi-\pi$ stacking with G-quartets. From this point of view, large porphyrin ligands may be preferable as their molecules perfectly overlap with G-quartets. Moreover, the porphyrins are selectively taken up by tumor cells, so the design of porphyrin-based anticancer drugs is a promising strategy in medicinal chemistry.

We have thus synthesized a series of derivatives of the natural porphyrin Pheophorbide- $a$ and synthetic tricationic porphyrin TMP3 (Fig. 3). They have indeed demonstrated an efficient binding to G4 DNA, telomerase inhibition and good antiproliferative activity.

Pheophorbide- $a$ (5a, Pheo- $a$ ) is currently used in photodynamic therapy of tumors. However, its anionic character prevents its interaction with nucleic acids, 
and water solubility of (5a) and its methyl ester (5b) is low. Cationic derivative of labile Pheo- $a$ containing trimethylammonium group on a short linker $(\mathbf{5 c}$, CatPheoa) was obtained for the first time to improve both the solubility and DNA binding affinity.

CatPheo- $a$ interaction with double-stranded poly (A).poly $(\mathrm{U})$, poly $(\mathrm{G}) \cdot \operatorname{poly}(\mathrm{C})$ and four-stranded $\operatorname{poly}(\mathrm{G})$ was studied by absorption and fluorescence spectroscopy techniques in a wide range of molar phosphate-todye ratios (P/D) [20]. Two types of binding were revealed: dye intercalation between the nucleic bases and external cooperative binding via the electrostatic interaction of the dye to polynucleotide backbones. The last type is predominant for double-stranded polynucleotides. In the case of four-stranded poly $(\mathrm{G})$, the external binding prevails at $\mathrm{P} / \mathrm{D}<5$, whereas under high $\mathrm{P} / \mathrm{D}$ values the intercalative binding is mainly realized which is accompanied with 4.5-fold fluorescence enhancement. Electrostatic interaction with nucleic acids was investigated on a model (5c)-polyphosphate system [21].

To study the intercalative type of Pheo- $a$ binding in its pure form we have used its neutral methyl ester $(\mathbf{5 b}$, MePheo- $a$ ) [22]. Substantial spectral changes, including the 50-fold increase of dye emission intensity, evidence its intercalation into four-stranded structures. In contrast, the binding to double-stranded polynucleotides and native DNA is accompanied by insignificant spectral transformations, with no more than 4-fold fluorescence enhancement, due to incorporation of $(\mathbf{5 b})$ into a double helix groove, presumably, in the dimeric form.

Since the binding of MePheo- $a$ to quadruplex DNA induces great increase of fluorescence, this dye, and to a lesser extent $(\mathbf{5 c})$, is a good fluorescent probe for monitoring G4 structures. Currently we are studying the effect of these compounds on telomerase activity.

A number of cationic porphyrins, including extensively studied tetra-(4-N-methylpyridinium)porphine (TMPyP4), have been identified as G4-interactive agents that inhibit telomerase (see reviews $[5,7,14$, 16]). TMP3 is a tricationic analog of TMPyP4 suitable for the conjugation to other molecules, e. g. oligonucleotides [23-25]. To increase the affinity of porphyrin to G4 DNA it was proposed to link TMP3 to aminoquinoline intercalating agent [26].

We have obtained and studied a series of TMP3 derivatives (Fig. 3). For the first time, TMP3 was cova- lently attached to imidazo[4,5-d]phenazine (ImPhz). Previously we have shown that $\mathrm{N}_{1}$-riboside of this dye is an intercalating agent efficiently stabilizing duplex and triplex DNA [27, 28], and oligonucleotides containing this nucleoside inhibit transcription and translation in mollicutes [29]. A non-nucleoside ImPhz derivative suitable for conjugation reactions was developed, and incorporation of this group into oligonucleotides was shown to stabilize complementary DNA duplexes via the intercalation mechanism $[30,31]$. It was expected that porphyrin fragment of the conjugate (7) would stabilize G-quartets, whereas ImPhz group could enhance the affinity by intercalating into double-stranded region of telomeric DNA, or between G-quartets. So TMP3imidazophenazine conjugates $(\mathbf{7 a}, \mathbf{b})$ with different linkers and their $\mathrm{Zn}(\mathrm{II})$ and $\mathrm{Mn}(\mathrm{III})$ complexes were obtained [32]. Trimethylammonium group was introduced into (6b) for additional binding to the phosphates.

The interaction of TMP3 (6a) with polynucleotides and quadruplex-forming oligonucleotide Tel22 (22-mer sequence d[AGGG(TTAGGG)3] of human telomere) was investigated by spectroscopic methods [33]. Three types of competitive binding mechanisms were revealed which are characterized by different changes in spectral parameters: (i) intercalation of the porphyrin between nucleic bases, (ii) its embedding into polynucleotide grooves, and (iii) external stacking-association on polyanionic backbone. At low P/D the last mechanism is dominating. It was modeled by the dye binding to inorganic polyphosphate, where the self-assembly of (6a) with a formation of $\mathrm{J}$ - and $\mathrm{H}$-aggregates was established. Molecular modeling provided the structures of aggregates formed by TMP3 molecules arranged in parallel or antiparallel mode [34].

Spectral characteristics of TMP3-ImPhz and its $\mathrm{Zn}$ complex (e.g. fluorescence quenching of both dyes) evidence the formation of internal heterodimers with stacking between porphyrin and phenazine rings. In the case of Mn-TMP3-ImPhz it has not occurred, perhaps due to the coordination of two axial water ligands by $\mathrm{Mn}^{3+}$ ion. Quantum-chemical study of the conjugates (7) by DFT (Density Functional Theory) method confirmed possible formation of intramolecular complexes where ImPhz directly interacts with a porphyrin. Two structures are realized depending on the presence of metal cation in a porphyrin ring (Fig. 4). Non-metalated hybrid 

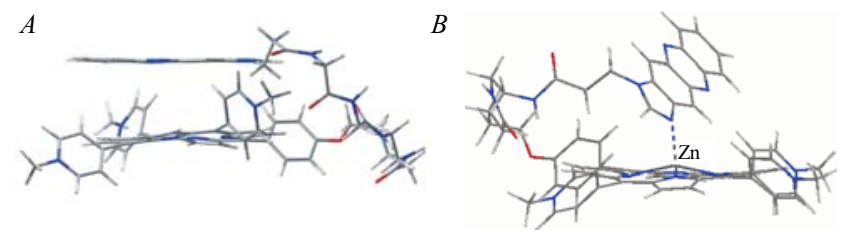

Fig. 4. DFT structures of the conjugate $7 \mathbf{b}(A)$ and its $\mathrm{Zn}(\mathrm{II})$ complex $(B)$

adopts the conformation with coplanar chromophores stabilized by stacking $(A)$. For $\mathrm{Zn}$ derivative, the metal coordination with a nitrogen atom of ImPhz fragment results in the formation of the other type of complex $(B)$. The folding of linear conjugate is energetically very favorable. For example, $\Delta \mathrm{G}_{298}$ of this process for $\mathrm{Zn}$ (7b) in vacuum and water is 15.61 and $12.34 \mathrm{kcal} / \mathrm{mol}$, respectively. Thus, the solvent does not significantly affect the formation of heterodimer; the structure of the linker between chromophores has quite limited effect as well [32].

Studies on the interaction of conjugates (7) with intermolecular G-quadruplex formed by poly $(\mathrm{G})$ revealed that both dyes bind to the polynucleotide. The porphyrin moiety forms complexes of two types with G4 structure. Under low $\mathrm{P} / \mathrm{D}$ values the outside binding accompanied by the stacking-association of porphyrin molecules along the polynucleotide backbone takes place (with the exception of Mn-TMP3-ImPhz) It successfully competes with another interaction mode which becomes dominant under high $\mathrm{P} / \mathrm{D}$, namely the nonintercalative binding, evidently by insertion of the porphyrins into poly $(\mathrm{G})$ groove. The phenazine part of all hybrids binds to polynucleotide by intercalation [35].

The interaction of conjugates and their metal complexes with intramolecular G-quadruplex Tel22 was also studied [36]. All the hybrids have high binding affinity to the quadruplex, probably via the external groove binding of the porphyrin. Small emission of Mn-TMP3 increases ca. 20-fold upon the binding. It was found that Zn- and Mn-TMP3-ImPhz stabilize G4 structure increasing its melting point by $3{ }^{\circ} \mathrm{C}$, whereas non-metalated hybrid decreases it by ca. $2^{\circ} \mathrm{C}$. In the case of metal complexes, 10 -fold increase in the Tel22 folding equilibrium constant at $37{ }^{\circ} \mathrm{C}$ was determined, so these compounds quite efficiently stabilize the quadruplex structures.

Biological activity of porphyrin derivatives. The effect of porphyrins on telomerase activity was evalua- ted in the TRAP assay [37]. All of them inhibited telomerase at micromolar concentrations. Almost complete inhibition was achieved with TMP3 methyl ester (6a) and TMP3-ImPhz (7a), as well as with TMPyP4, at $6 \mu \mathrm{M}$ concentration. It is interesting to note that the activity of (7a) at $12 \mu \mathrm{M}$ was lower than that at $6 \mu \mathrm{M}$, perhaps due to the aggregation at higher concentrations. As expected, compound (6b) containing phosphate-binding $\mathrm{Me}_{3} \mathrm{~N}^{+}$group appeared to be several times more active and efficiently inhibited the telomerase at $2 \mu \mathrm{M}$. Zinc complex of the conjugate was the most active compound almost completely inhibiting the enzyme at $1 \mu \mathrm{M}$ concentration. $\mathrm{Mn}$ (III) complex was less active.

Thus, TMP3 derivatives are potent telomerase inhibitors in vitro. Two of them are comparable to TMPyP4 standard, whereas cationic derivative (6b) and $\mathrm{Zn}$ (II) complex of TMP3-ImPhz conjugate are much more active.

Antiproliferative activity of several TMP3 derivatives was investigated in vitro. TMP 3 conjugate (7a) and its $\mathrm{Zn}(\mathrm{II})$ complex, as well as compounds (6a) and (6b), were tested in the cultures of human tumor cells HeLa and MCF-7 (MTT assay). The last two compounds demonstrated EC50 values in the range $6-8 \mu \mathrm{M}$ on $\mathrm{HeLa}$ cells, whereas MCF-7 cells were more susceptible to these drugs $\left(\mathrm{EC}_{50} 0.2-0.7 \mu \mathrm{M}\right)$. Conjugates were more active, with EC50 0.1-0.4 $\mu \mathrm{M}$ for non-metalated hybrid (7a). At the same time, its $\mathrm{Zn}$ (II) complex demonstrated very high activity in HeLa cell culture $\left(\mathrm{EC}_{50}\right.$ as low as $20 \mathrm{nM}$ ).

It should be noted that antiproliferative activity of TMP3 derivatives correlates well with the data on telomerase inhibition obtained in the TRAP assay.

TMP3-ImPhz hybrids (7b) were tested on mouse Lewis lung carcinoma cells (LLC line) [32]. This line of tumor cells was in part selected since they can be grafted in mice, so it is a good model for in vivo experiments. Incorporation of $\left[{ }^{3} \mathrm{H}\right]$-thymidine was used for the quantitative analysis. All the conjugates demonstrated good antiproliferative activity, and metal complexes were several times more active than non-metalated hybrid. Experimental $\mathrm{EC}_{50}$ values for non-metalated (7b), its $\mathrm{Mn}$ and Zn complex were $21.8,11.2$ and $5.9 \mu \mathrm{M}$, respectively. These values are comparable to those of known anticancer drugs doxorubicin and vincristine. So the conjugates of G4 ligand TMP3, especially their metal complexes, efficiently suppress LLC mouse tumor cells in vitro. 
Molecular modeling in the study of telomerase inhibitors. Computer modeling of the structures of G4 ligands and their interaction with G-quadruplexes was always an integral part of our research. The availability of crystallographic and NMR data for G4 structures [10, 12] allows the development of new antitumor drugs using computational methods. Modeling was based on quantum chemistry approaches, rather than docking or molecular dynamics common for drug design. Both semiempirical and non-empirical methods were employed. First, a comprehensive analysis of G-quadruplex structures was carried out. Studies on G-quartets and G-octets as structural elements of G-quadruplexes were performed in vacuum and in aqueous medium [38]. Guanine quartets in vacuum were found to have not only the Hoogsteen or bifurcated, but also a mixed system of hydrogen bonds; in water the latter two forms are easily transformed into the classic Hoogsteen structure. For G-octets, four stable configurations with D4, C4 and S4 symmetry formed by the pairs of guanine quartets with Hoogsteen, bifurcated or mixed H-bonds were identified. Most important, S4-structure consisting of the pair of mixed Hoogsteen-bifurcated type G-quartets was shown to be the most advantageous structure of G-octet in water.

We have proposed G-octet, a pair of G-quartets stabilized by $\pi-\pi$ interactions and containing a $\mathrm{K}^{+}$or $\mathrm{NH}^{4+}$ cation located between the quartet planes, as a simple model of natural G-quadruplexes (consisting usually of three or four G-quartets) suitable for the calculations of G4-ligand binding energies and complex geometries [38]. It was used e. g. to model TMP3-ImPhz binding to G4: it was found that phenazine moiety can interact with a surface of porphyrin ring or G-quartet, but its intercalation between G-quartets is less favorable. It was shown for many types of compounds that the calculated energies of interaction with G-octets correlated with their biological activity.

For the calculations of more complex molecular systems we have successfully applied a hybrid QM/MM (quantum mechanics - molecular mechanics) approach ONIOM2 [39]. This method combines high accuracy QM calculations in the spatially restricted functionally important region of the system (high layer) with less accurate, but much faster MM calculations in the remaining part (low layer). It was employed to model the in- teraction of small molecules with full-size Tel22 quadruplex (PDB code 1KF1). This method is suitable for charged ligands able to interact with phosphates, for which G-octet model cannot provide correct binding data (Fig. 5).

ONIOM modeling allows finding optimal structures of G4-ligand complexes and determining binding energies. It also provides valuable information on possible structural modification of the ligands to improve their binding efficiency, e. g. linker length and structure, number and orientation of the substituents, etc. For example, it is clear from Fig. 5 that the introduction of the second cationic group on an appropriate linker into acridone structure A would result in the increase of binding energy due to its interaction with the second phosphate group.

Conclusion. The aim of our research is to find efficient G4 ligands that would be able at the same time to discriminate between different forms of nucleic acids in order to be specific for telomeric DNA. The binding of small molecules to G4 DNA and their activity as telomerase inhibitors depend on the size, shape and charge of the central aromatic ring, the nature of its substituents and electronic density distribution in the molecule. Efficient G4-ligands should contain planar aromatic areas that bind to G-quartets. However, the size of trcyclic molecules seems to be just insufficient to ensure the highest affinity interaction with large G-quartets, although this can be compensated by the substituents binding to phosphate anions; perhaps in the case of tricyclic ligands one substituent of cationic character is not sufficient for strong G4-ligand binding. Cyanines containing both cationic aromatic core able to overlap with two guanine residues and a basic substituent appeared to be much more efficient. At the same time, molecular and electronic structure of porphyrins allows them to match perfectly large planar surfaces of G-quartets.

The future research will be directed at increasing the affinity and selectivity of telomerase inhibitors for quadruplex DNA. Most G4 binders contain intercalating fragments and thus are not specific exclusively to quadruplex over duplex DNA that may result in nonspecific cytotoxicity. There is a number of ways to increase a quadruplex specificity of small molecules and their binding constants. Optimization of the core aro- 

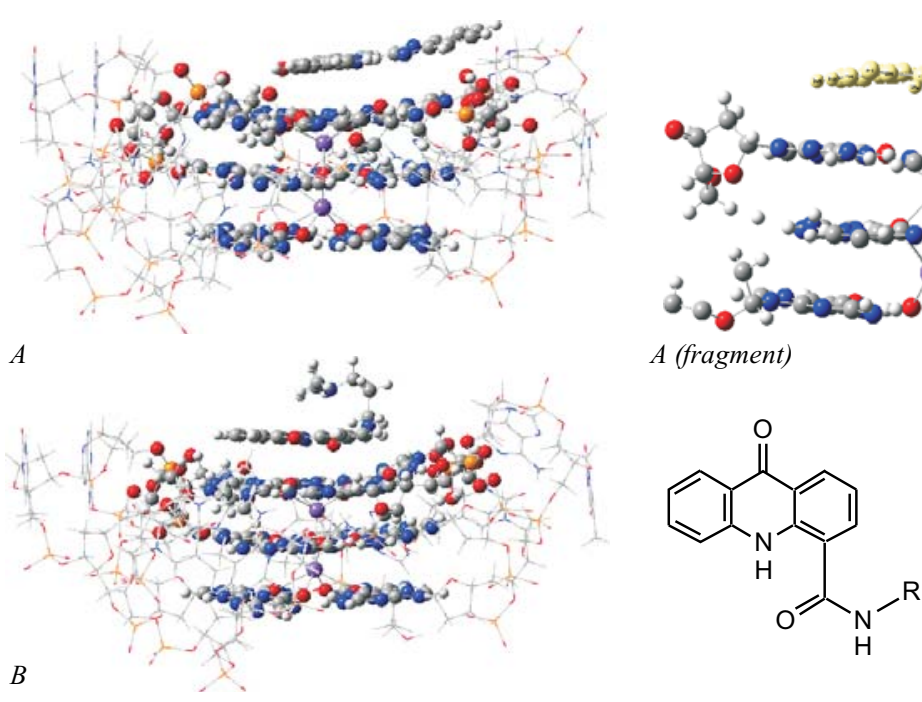

A:

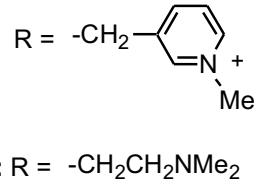

Fig. 5. ONIOM2 models of acridone complexes with Tel22 quadruplex (side view). High layer atoms are shown as spheres matic fragments would result in favorable ligand interaction with G-quartet. The introduction of structural moieties, binding in a specific manner to G4 grooves whose structural features differ from those in duplex DNA, or fragments able to interact with the loops of G4 structures, could provide additional contacts with quadruplex elements. These modifications would lead to strong and specific binding of synthetic molecules to quadruplex DNA and efficient inhibition of telomerase.

Acknowledgements. Authors thank Dr. V. Zozulya and Dr. O. Ryazanova for long time collaboration. This work was partially supported by Science and Technology Center in Ukraine (grant 3172), NAS of Ukraine (program «Fundamental basics of molecular and cell biotechnologies», grant 43/10) and the State program «Nanotechnologies and nanomaterials» (project 5.16.3.36).

\section{В. В. Негруцька, Л. В. Дубей, М. М. Ільченко, І. Я. Дубей}

Дизайн і вивчення інгібіторів теломерази на основі лігандів G-квадруплексів

\section{Резюме}

В огляді підсумувано основні результати наших недавніх досліджень інгібіторів теломерази та лігандів $G$-квадруплексної ДНК. Синтезовано й вивчено серію потениійних інгібіторів ферменту на основі трициклічних гетероароматичних систем (тіазолобензімідазоли, феназини, акридони), амінозаміщених иіанінів та природних і синтетичних порфіринів і їхніх металокомплексів. Знайдено низку сполук - ціанінів та особливо похідних і кон'югатів порфіринів, шуо ефективно інгібують теломеразу іn vitro за умов тесту TRAP у мікромолярних концентраціях. Порфірини у мікрота наномолярних концентраціях демонструють антипроліферативну дію в культурах пухлинних клітин. Спектрофлуоресиентними та електрофоретичними методами досліджено взаємодію лігандів з дуплексною та квадруплексною ДНК, у багатьох випадках визначено тип зв'язування. Взаємодію ліганд-мішень вивчено методами квантової хімії за використання G-октету як зручної моделі G-квадруплексу. Для моделювання зв'язування малих молекул з квадруплексною ДНК Теl22 застосовано гібридний QM/MMniдxiд ONIOM2.

Ключові слова: теломераза, G-квадруплекс, TRAP, протипухлинні засоби, порфірини, молекулярне моделювання.

\section{В. В. Негруичкая, Л. В. Дубей, Н. Н. Ильченко, И. Я. Дубей}

Дизайн и исследование ингибиторов теломеразы на основе лигандов G-квадруплексов

Резюме

В обзоре суммированы основные результаты наших недавних исследований ингибиторов теломеразы и лигандов $G$-квадруплексной ДНК. Синтезирована и изучена серия потенциальных ингибиторов фермента на основе трициклических гетероароматических систем (тиазолобензимидазоль, феназины, акридоньl), амино-замещенных ичианино, природных и синтетических порфиринов $и$ их металлокомплексов. Обнаружен ряд соединений-циианнов и особенно производных и конъюгатов порфиринов, эффективно ингибирующих теломеразу in vitro в условиях теста TRAP в микромолярных концентрациях. Порфирины в микро- и наномолярных концентрациях демонстрируют антипролиферативное действие в культурах опухолевых клеток. Спектрофлуоресиентными и электрофоретическими методами исследовано взаимодействие лигандов с дуплексной и квадруплексной ДНК, во многих случаях определен тип связывания. Взаимодействие лиганд-мишень изучено методами квантовой химии с использованием G-октета как удобной модели $G$-квадруплекса. Для моделирования связывания малых молекул с квадруплексной ДНК Tel22 применен гибридный QM/MM-подход ONIOM2.

Ключевые слова: теломераза, G-квадруплекс, TRAP, противоопухолевые средства, порфирины, молекулярное моделирование.

\section{REFERENCES}

1. Harley C. B. Telomerase and cancer therapeutics // Nat. Rev. Cancer.-2008.-8, N 3.-P. 167-179.

2. Rudolph K. L. Telomeres and telomerase in aging, disease, and cancer--Berlin-Heidelberg: Springer, 2010.-330 p.

3. Tian X., Chen B., Liu X. Telomere and telomerase as targets for cancer therapy // Appl. Biochem. Biotechnol.-2010.-160, N 5.P. 1460-1472. 
4. Ruden M., Puri N. Novel anticancer therapeutics targeting telomerase // Cancer Treat. Rev.-2012.-39, N 5.-P. 444-456.

5. De Cian A., Lacroix L., Douarre C., Temime-Smaali N., Trentesaux $C$., Riou J. F., Mergny J. L. Targeting telomeres and telomerase // Biochimie.-2008.-90, N 1.-P. 131-155.

6. Tarkanyi I., Aradi J. Pharmacological intervention strategies for affecting telomerase activity. further prospects to treat cancer and degenerative diseases // Biochimie.-2008.-90, N 1.-P. 156-172.

7. $X u Y$. Chemistry in human telomere biology: structure, function and targeting of telomere DNA/RNA // Chem. Soc. Rev.-2011.40, N 5.-P. 2719-2740.

8. Telomerase Inhibition: Strategies and Protocols / Eds L. Andrews, T. O. Tollefsbol.-Totowa: Humana press, 2011.-203 p.

9. Xu Y., Komiyama M. Structure, function and targeting of human telomere RNA // Methods.-2012.-57, N 1.-P. 100-105.

10. Neidle $S$. Human telomeric G-quadruplex: the current status of telomeric G-quadruplexes as therapeutic targets in human cancer // FEBS J.-2010.-277, N 5.-P. 1118-1125.

11. Collie G. W., Parkinson $G$. N. The application of DNA and RNA G-quadruplexes to therapeutic medicines // Chem. Soc. Rev.2011.-40, N 12.-P. 5867-5892.

12. Kaushik M., Kaushik S., Bansal A., Saxena S., Kukreti S. Structural diversity and specific recognition of four stranded G-quadruplex DNA // Curr. Mol. Med.-2011.-11, N 9.-P. 744-769.

13. Duchler $M$. G-quadruplexes: targets and tools in anticancer drug design // J. Drug Target.-2012.-20, N 5.-P. 389-400.

14. Monchaud D., Teulade-Fichou M. P. A hitchhiker's guide to G-quadruplex ligands // Org. Biomol. Chem.-2008.-6, N 4.P. 627-636.

15. Vy Thi Le T., Han S., Chae J., Park H. J. G-quadruplex binding ligands: from naturally occurring to rationally designed molecules // Curr. Pharm. Des.-2012.-18, N 14.-P. 1948-1972.

16. Paul A., Bhattacharya $S$. Chemistry and biology of DNA-binding small molecules // Curr. Sci.-2012.-102, N 2.-P. 212-231.

17. Gomez D., Mergny J. L., Riou J. F. Detection of telomerase inhibitors based on G-quadruplex ligands by a modified telomeric repeat amplification protocol assay // Cancer Res.-2002.-62, N 12.P. 3365-3368.

18. Xin H. Telomeric repeat amplification protocol: measuring the activity of the telomerase // Methods Mol. Biol.-2011.-735.P. 107-111.

19. Palchykovska L. G., Alexeeva I. V., Negrutska V. V., Kostyuk Yu. K., Indychenko T. M., Kostenko O. M., Kryvorotenko D. V., Shved A. D., Dubey I. Ya. Inhibition in vitro transcription by 2-arylidene derivatives of thiazolo[3,2- $\alpha$ ]benzimidazol-3(2H)-one // Biopolym. Cell.-2010.-26, N 6.-P. 508-511.

20. Ryazanova O. A., Voloshin I. M, Dubey I. Ya., Dubey L. V., Zozulya $V . N$. Spectroscopic studies on binding of cationic Pheophorbide- $a$ derivative to model polynucleotides // IFMBE Proceedings.-Berlin-Heidelberg: Springer, 2008.-Vol. 20.-P. 397-400.

21. Ryazanova O., Voloshin I., Dubey I., Dubey L., Zozulya V. Fluorescent studies on cooperative binding of cationic Pheophorbide- $a$ derivative to polyphosphate // Ann. N. Y. Acad. Sci.2008.-1130.-P. 293-299.

22. Ryazanova O. A., Voloshin I. M., Dubey L. V., Zozulya V. N. Spectroscopic investigation on binding of the methyl ester of Pheophorbide- $a$ to synthetic polynucleotides and DNA // Biophys. Bull. (Kharkiv).-2009.-23, N 2.-P. 20-29.

23. Dubey I., Pratviel G., Meunier B. Preparation of cationic nonmetallated- or zinc-porphyrin-oligonucleotide fluorescent conjugates // Compt. Rend. Acad. Sci. (Paris), Ser. II C.-1998.-1, N 4.-P. 259-267.

24. Dubey I., Pratviel G., Meunier B. Modification of the thiourea linkage of fluorescein-oligonucleotide conjugate to a guanidi- nium motif during ammonia deprotection // Bioconjug. Chem.1998.-9, N 5.-P. 627-632.

25. Dubey I., Pratviel G., Meunier B. Synthesis and DNA cleavage of 2'-O-amino-linked metalloporphyrin-oligonucleotide conjugates // J. Chem. Soc. Perkin 1.-2000.-18.-P. 3088-3095.

26. Maraval A., Franco S., Vialas C., Pratviel G., Blasco M. A., Meunier $B$. Porphyrin-aminoquinoline conjugates as telomerase inhibitors // Org. Biomol. Chem.-2003.-1, N 6.-P. 921-927.

27. Zozulya V., Shcherbakova A., Dubey I. Calculating helix-to-coil transitions of duplexes formed by phenazine-conjugated oligonucleotide, using fluorescence melting data // J. Fluoresc.2000.-10, N 1.-P. 49-54.

28. Zozulya V., Blagoi Yu,, Dubey I., Fedoryak D., Makitruk V., Ryazanova $O$., Shcherbakova A. Anchorage of an oligonucleotide hybridization by a tethered phenazine nucleoside analogue // Biopolymers.-2003.-72, N 4.-P. 264-273.

29. Skripal' I. H., Babichev V. V., Panchenko L. P., Iegorov O. V., Korobkova K. S., Dubey I. Y., Fedoryak D. M., Shalamay A. S. Antisignature oligonucleotides and their analogs as inhibitors of mollicutes-cofactors of HIV // Mikrobiol. Z.-1997.-59, N 2.P. 3-11.

30. Dubey L., Ryazanova O., Zozulya V., Fedoryak D., Dubey I. Postsynthetic modification of oligonucleotides with imidazophenazine dye and its effect on duplex stability // Nucleosides Nucleotides Nucleic Acids.-2011.-30, N 7-8.-P. 585-596.

31. Ryazanova O., Dubey L., Dubey I., Zozulya V. Spectroscopic study on the effect of imidazophenazine tethered to 5 '-end of pentadecathymidilate on stability of poly $(\mathrm{dA}) \cdot(\mathrm{dT})_{15}$ duplex // J. Fluoresc.-2012.-22, N 6.-P. 1431-1439.

32. Dubey L. V., Ilchenko M. M., Zozulya V. N., Ryazanova O. A., Pogrebnoy P. V., Dubey I. Ya. Synthesis, structure and antiproliferative activity of cationic porphyrin-imidazophenazine conjugate // Int. Rev. Biophys. Chem.-2011.-2, N 4.-P. 147-152.

33. Zozulya V., Ryazanova O., Voloshin I., Glamazda A., Karachevtsev V., Dubey I., Pratviel G. Spectroscopic studies on interactions of a tricationic porphyrin derivative with polynucleotides // $12^{\text {th }}$ Eur. Conf. «Spectroscopy of Biological Molecules» (Bobigny, France, 1-6 Sept. 2007): Abstracts.-Bobigny, 2007.- P. 129.

34. Zozulya V. N., Ryazanova O. A., Voloshin I. M., Glamazda A. Yu., Karachevtsev V. A., Dubey L. V., Dubey I. Ya. Spectroscopic studies on interactions of tricationic porphyrin derivative with polynucleotides // V Congress of Ukr. Biophys. Soc.: Abstract book (Lutsk-Svityaz, 22-25 June 2011).-Lutsk, 2011.-P. 16.

35. Zozulya V., Ryazanova O., Voloshin I., Dubey L., Dubey I. Spectroscopic studies on binding of porphyrin-phenazine conjugate to Gquadruplexes formed by poly $(\mathrm{G}) / /$ Int. Conf. «Conformational Diversity and Application of G-Quadruplexes» (Barcelona, Spain, October 6-8 2012): Abstract.-Barcelona, 2012.-P. 114-115.

36. Zozulya V. N., Ryazanova O. A., Voloshin I. M., Dubey L. V., Dubey I. Ya. Spectroscopic studies on binding of porphyrinphenazine conjugate to intramolecular G-quadruplex formed by 22-mer oligonucleotide // Int. Rev. Biophys. Chem.-2011.-2, N 4.-P. 112-119.

37. Negrutska V. V., Dubey L. V., Kuziv Ia. B., Dubey I. Ya. In vitro telomerase inhibition by cationic porphyrin derivatives // III Int. Symp. «Intracellular Signalling and Bioactive Molecules Design» (Lviv, Ukraine, 17-23 September 2012): Abstract.Lviv, 2012.-P. 144.

38. Ilchenko M. M., Dubey I. Ya. Density functional study of the structure of guanine octets in aqueous medium // Int. Rev. Biophys. Chem.-2011.-2, N 3.-P. 82-86.

39. Vreven T., Morokuma K. Hybrid methods: ONIOM(QM:MM) and QM/MM // Annu. Rep. Comp. Chem.-2006.-2.-P. 35-51.

Received 10.01.13 